\title{
Global Efforts to liberalize World Trade in Services
}

\author{
John Mylonakis (Corresponding author) \\ E mail: imylon@otenet.gr
}

Received: February 10, 2019 Accepted: February 19, 2019 Published: February 20, 2019

doi:10.5296/rbm.v6i1.14377ＵRL: http://dx.doi.org/10.5296/rbm.v6i1.14377

\begin{abstract}
In every international or global trade summit, one can easily find the element of the Services. Nonetheless, Services companies continue to encounter obstacles to entering and operating in new markets, due to various protectionist measures in host countries. International negotiations help to globalize the Trade in Services and apply international standards and rules to facilitate information flow and partnerships, which increase world trade and further develop international trade relations. The existence and implementation of international standards and rules in all areas of the Services could facilitate the flow of information and partnerships that would increase world trade and improve international trade relations. Efforts to reach a new world agreement in Services are constantly stumbling into the refusal of the Least Developed and Developing Countries to curb the various policies of protectionism and free market penetration. The example of BRICS (Brazil, Russia, India, People's Republic of China, South Africa) may be a good paradigm in international negotiations but still to be proved.
\end{abstract}

Key words: Trade in Services, International Trade Negotiations, World Trade Organization, BRICS

\section{Trade in Services}

Services are the most growing sector in the global economy as trade in Services and foreign direct investment in the region is increasing at a faster rate than trade in goods over the past decades (Ghani \& Kharas, 2010). In Developed and in most developing countries, the contribution of the Services to GDP is now more than 80 to $85 \%$. Services are nowadays complex by being combined with commodity production, trade and consumption. Their degree of participation in each of these areas has not been clearly and precisely explored (Low, 2016). A growing number of industrial companies globally buy, produce and sell services, hire people of the Services sector, the final product of which they sell in the markets (servicification). In this way, the liberalization of Trade in Consumer Products (goods) is directly linked to that of Trade in Services (Kommerscollegium, 2016). However, the development of international trade in Services, as well as, in other areas of the economy (including copyright), is neither self-evident, nor automatic, nor confident, nor without obstacles. It is carried out through voluntary coalitions of States at bilateral, multilateral and/or plurilateral level, following hard and long-term negotiations between well-informed players and economic and commercial interests. 


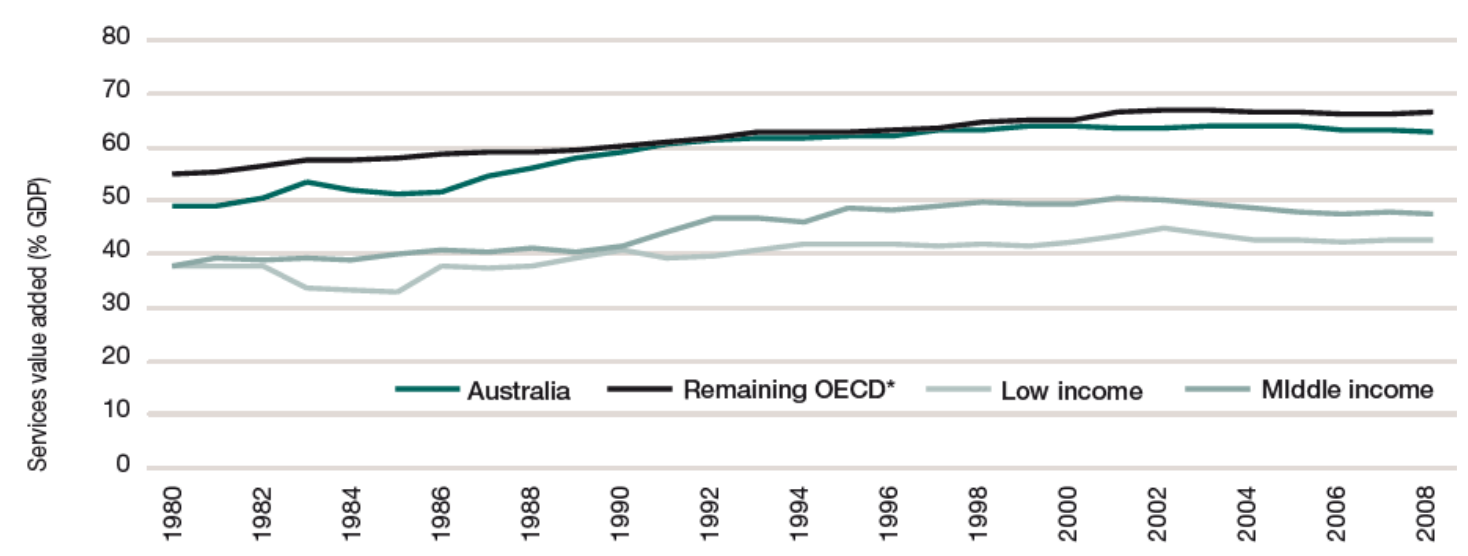

Note: for country groupings see World Bank website: www.worldbank.org

Data source: World Bank World Development Indicators online database and CIE estimations.

The existence and implementation of international standards and rules in all areas of the Services could facilitate the flow of information and partnerships that would increase world trade and improve international trade relations. The question to be answered is whether the liberalization of the establishment and operation of businesses and employees in them increases or decreases competition, the quality of the services provided, the reliability of financial data and the application of international standards (accounting, tax, financial). If the answer is positive, then it is necessary to examine the policies, possibilities and ways of operating the development methods of these enterprises, either at national, regional or global level, which is not yet the case. If the answer is negative, then the increase in the entry barrier for new businesses must really justify increasing the restrictive policies of domestic markets from business risk, as well as, standards that are inconsistent with the host country regime. Typically, countries that deny freedom of establishment point to fears that foreign firms will subdue domestic and weak companies which will either close or be absorbed by large (multinational) and experienced large companies.

\section{Real GDP gains arising from service trade liberalisation ${ }^{a}$}

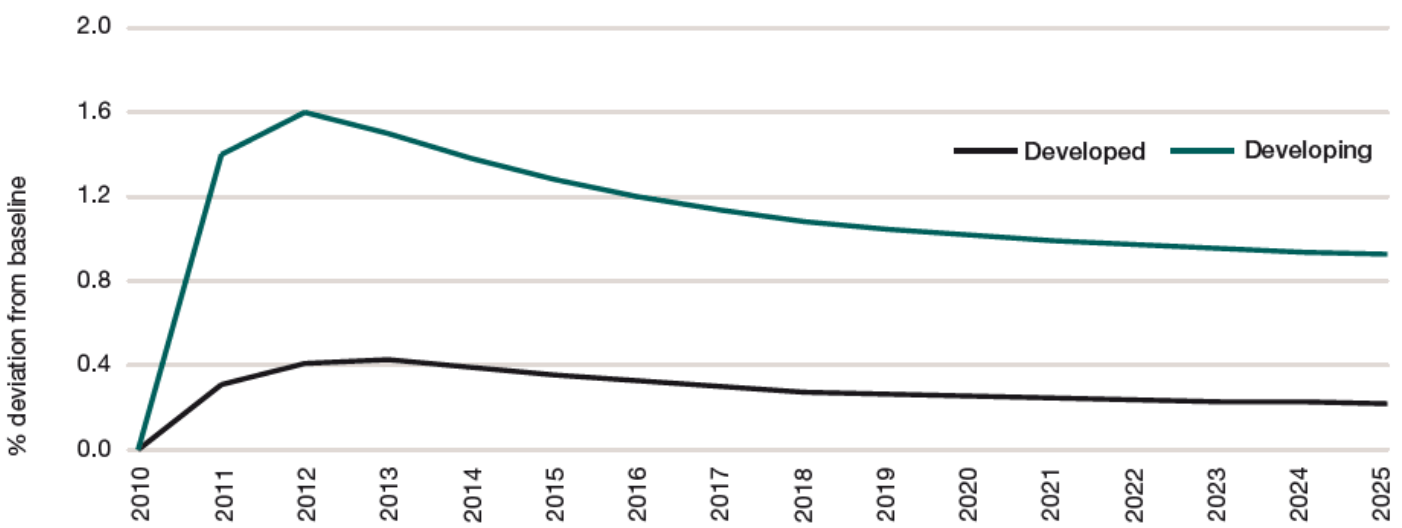

a Aggregate GDP impacts for the developed and developing country groupings have been derived from indlvidual country results, aggregated using GDP weights. Services trade liberallsation involves removal of barriers to services trade via Mode 1 and Mode 3 , that is, Barriers to the Dellvery of Services Overseas and Services-Related Investment.

Data source: CIE-GCubed modelling simulation. 
A classic example is Accounting, Taxation and Auditing Services. The structure and organization of these Services is progressively globalizing, despite international crises, and it is expanding as 111 countries committed themselves (December 2016) to creating new auditing standards. These standards will make auditing procedures and reports more qualitative, informative and transparent, with the introduction of ISA701, and the requirement for audit firms to focus on specific audit issues, separately for each controlled company (Montgomery, 2016).

\section{International Negotiations of Services}

In every international or global trade agreement, there is the element of the Services and the freedom of establishment of workers in this field. Nonetheless, service firms continue to encounter obstacles to entering and operating in new markets, as well as workers in them, by protectionist measures in host countries. Decades of negotiations on Trade in Services produced a multitude of rules and commitments, but eventually little actual release of the Services took place (Matoo, 2015).

Especially for Trade in Services, negotiations for their liberation have been extremely important in recent years. It should be noted that until 2008, the issue of Trade in Servic es to the World Trade Organization (WTO) was marginal, and in any case negligible, as the burden of negotiations was exclusively on Trade in Agricultural and Industrial Products. Since July 2008, Member States participating in the Trade Commission for Services in the WTO have tried to fill the lost ground at multilateral level, even though they still fall short of the objectives of a new General Agreement on Trade in Services GATS).

The General Agreement of Trade in Services (GATS, 1995) is the most significant example of an attempt to liberalize the Services sector worldwide. It is, also, the most important of a new global attempt to widen the scope of application of Services on modern bases, whether these are autonomous services or services associated with the production of a good. As the tensions and disputes between commercial and non-partner countries grow, the risk of expanding severe impacts on the global economy, such as a reduction in trade volume and employment, is increasing. China's recent cases of alleged violation of intellectual property rules and the use of compulsory technology transfer, and the US, for imposing tariffs on steel and aluminum products, are typical (Porges, 2018).

Under the WTO, Trade in Services is covered by the General Agreement on Trade in Services and includes Business Services, Financial and Insurance Services, Telecommunications, Education, Electronic Commerce, Postal and Transportation Services, Architectural and Engineering Services and Environmental and Tourism Services (Adlung \& Mamdouh, 2013). It also includes the provision of all categories of Services at cross-border level (mode 1), use (consumption) of Services abroad (mode 2), direct investment for commercial services (mode 3 ) and physical presence abroad (mode 4). Recently, a new major category of Services (Antimiani \& Cernat, 2017) has been added to the above categorization of Services, which covers the full range of Services integrated into the production chain of goods (e.g. technology, design, energy) and are part of the exported finished industrial goods (mode $5)$. 


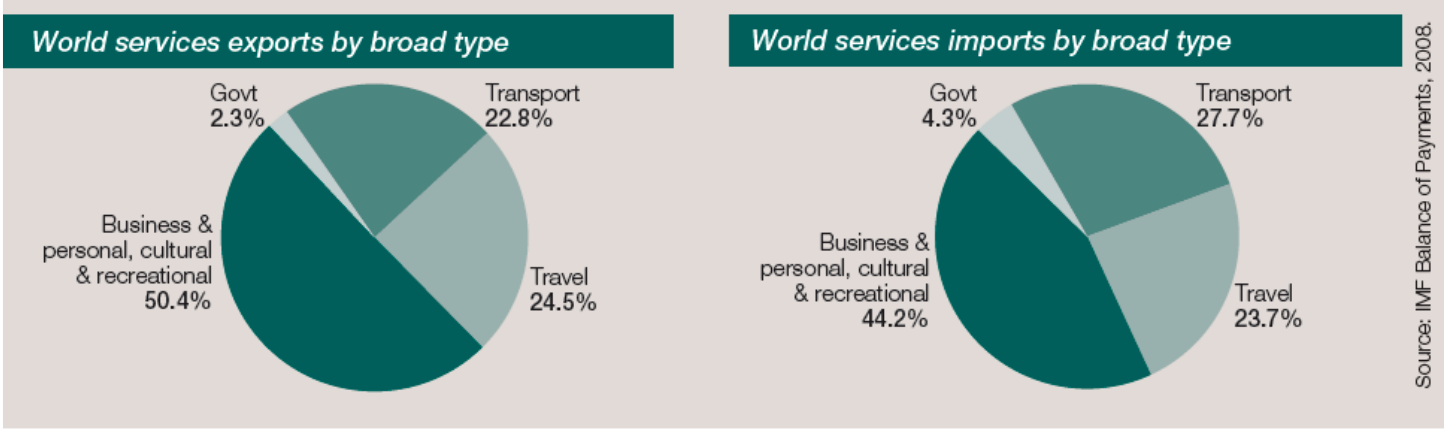

In the WTO, negotiations aiming at the liberalization of Trade in Services are made through the adoption of rules at four main levels:

1. National regulations. It concerns Certificates of Fitness, Service Licenses and

Technical Facilities.

2. Urgent safeguard measures. It concerns the identification of measures taken in the event that imports of Services cause damage to domestic service providers.

3. Subsidies. It is about identifying subsidies for those who distort Trade in Services through subsidies to production, investment, exports and consumption of Services. 4. Government Procurement. In December 2011 the new negotiation of the revised

Government Procurement Agreement was signed.

Efforts to close a new world agreement in Services are constantly stumbling into the refusal of the Least Developed and Developing Countries to curb the various policies of protectionism and free market penetration, policies that restrict economic growth and make world trade cooperative difficult, if not impracticable. Indeed, at a time when the WTO Dispute Settlement Mechanism, as an International Commercial Court, is under questioning and understaffing (Gao, 2018).

The challenge of World Trade Organization, as a global trading forum is intense, with hopes for its possible revitalization limited. Typically, the WTO is like a train without a machine. The machine is China and the US, whose leaders cannot run the train. The most important difficulty in its operation is the constitutional requirement for Member States' unanimity procedure, as a prerequisite for reaching agreement on any decision.

The oxymoron in the WTO is that despite the general inactivity and depreciation of this institution, most Member States want to negotiate, struggle to reach an agreement and/or show to be struggling for the future of the Organization. For this reason, they also use substitutes for formal negotiation schemes, such as plurilateral agreements, which are considered to be more flexible, rapid and transparent negotiation procedures between voluntary contracting Member States. The prime example is 'Real Good Friends of the Services', a group of 21 Member States seeking to reach agreement among themselves on more than 100 trade issues relating to the liberalization and development of Trade in Services.

\subsection{The Greek case}

In terms of Greek interests, emphasis is placed on the negotiations concerning Shipping, Tourism, Construction, Telecommunications, Financial and Environmental Services (mode 3). Also, special attention is needed at the request of Developing Countries to increase the time spent by a skilled labor force for the provision of Outsourced Services (mode 4). 
The Services sector in Greece is particularly important for the Greek economy, accounting for $2 / 3$ of the country's GDP. The receipts from Greek exports of services far exceed the receipts from exports of goods. In all Developed and Developing Countries, the Services sector is growing faster than the Agriculture and Industry sectors. In Developed Countries it accounts for more than $70 \%$ of its GDP, while exports of its services account for almost 1/5 of international trade. The European Union is the world's largest importer and exporter of services worldwide, followed by the countries of Asia and North America. Greece's important position in world trade in services is due to the strong growth in exports to the Shipping and Tourism Services as well as to the Construction sector (manufacturing companies in Eastern Europe and the Middle East).

Law 3844/2010 (Government Gazette 63/63 / 3-5-2010) adapts the Greek legislation to the provisions of Directive 2006/EC of the European Parliament and of the Council of 12 December 2006 on Services in the internal market. In particular, it lays down general provisions facilitating the exercise of the freedom of establishment of service providers and the freedom to provide services by maintaining a high quality of service. The law applies to the Services of providers established in a Member State of the European Union (Article 4), in compliance with the rules of the Lisbon Treaties governing the right of establishment and the free movement of services (Article 5, 3).

\section{The International Trends in Commerce}

Global trends are such that the countries with the largest developing and emerging economies are forced to unite. They look for initiatives, under different names, but for one purpose: to cope with global disorder and to develop economic and trade relations with each other. The best example is the case of BRICS (Brazil, Russia, India, People's Republic of China, South Africa). BRICS currently accounts for around $43 \%$ of the world's population, $18 \%$ of Gross World Product, and their total foreign exchange reserves amounted to US \$ 4 trillion. The trade between them has already exceeded 500 billion US dollars.

Although the individual political and economic objectives of the BRICS countries do not seem to be the same, their leaders manage to meet, discuss and co-decide on a number of international issues over the past 10 years, proposing changes to the role of the International Monetary Fund and the World Bank, of the Doha Round negotiations within the World Trade Organization, the fight against terrorism, the Middle East war, North Africa and the Horn of Africa. A common feature of these countries is the diversity of their political systems and the level of economic growth. Instead, their leaders estimate that these differences can be seen as common opportunities and growth opportunities for their economies. The five BRICS Summits have shown that the leaders of these countries can have a common presence on the world stage, and for various political and economic issues, despite their conflicting interests.

\section{Conclusions}

In conclusion, the above-mentioned efforts of the States to join in groups, both at world (WTO) and at regional levels (PTAs), seek to achieve International Cooperation in the field of Services.

Today, all forms of the Services have been internationalized, whether they are autonomous (financial, accounting, tax), or are attached to some goods (consumer products). The present form of States' cooperation does not satisfy Services providers, as already reached agreements in central decision-making bodies are not easy to implement, exhibiting uncertain future. Also, liberalization efforts at international level are quite low, compared to committed ones from the Heads of States. The inherent fear of most governments over large and 
international providers is still apparent: they are afraid that large businesses can harm consumers' interests and cause economic and commercial turmoil in host countries.

\section{References}

Adlung, R., \& Mamdouh, H. (2013). How to design Trade Agreements in Services - Top Down or Bottom Up?. World Trade Organization, June, pp. 1-20

Antimiani, A., \& Cernat, L. (2017). Liberalizing Global Trade in Mode 5 Services. How much is it worth? DG TRADE European Commission, 4, 1-19.

Gao, H. (2018). The WTO Dispute Settlement Mechanism: A Trade Court for the World. RTA Exchange, Geneva: International Centre for Trade and Sustainable Development (ICTSD) and the Inter-American Development Bank (IDB)

Ejaz, G., \& Kharas, H. (2010). The Service Revolution, Economic Premise, The World Bank, No 14 , pp. 1-5

González, A. (2018). Strengthening the Conditions for Global Cooperation on International Trade, Geneva: International Centre for Trade and Sustainable Development (ICTSD)

Kommerscollegium. (2016). The Servicification of EU Manufacturing, October, National Board of Trade Sweden

Low, P. (2016). Rethinking Services in a Changing World, E15 Expert Group on Services Policy Options Paper, E15Initiative, Geneva: International Centre for Trade and Sustainable Development (ICTSD) and World Economic Forum

Mattoo, A. (2015). Services Trade and Regulatory Cooperation, E15Initiative, Geneva: International Centre for Trade and Sustainable Development (ICTSD) and World Economic Forum

Montgomery, Roger (2016). International Auditing Tightens. Retrieved from https://rogermontgomery.com/international-auditing-and-assurance-standard-board-iaasb/

Porges, A. (2018). Designing Common but Differentiated Rules for Regional Trade Disputes. RTA Exchange, Geneva: International Centre for Trade and Sustainable Development (ICTSD) and the Inter-American Development Bank (IDB)

Saran, S. (2017). The next ten year of BRICS - will the relationship LAST?, World Economic Forum. Observer Research Foundation (ORF)

\section{Copyright Disclaimer}

Copyright reserved by the author(s).

This article is an open-access article distributed under the terms and conditions of the Creative Commons Attribution license (http://creativecommons.org/licenses/by/3.0/). 